\section{Proliferation}

United States non-proliferation policy is facing its toughest domestic test for almost a decade, as Congress decides whether or not to veto President Carter's decision to allow the further export of nuclear fuel to the Tarapur nuclear power plant in India. The Nuclear Regulatory Commission (NRC) has already ruled that the export of 38 tons of enriched uranium requested by India would violate the Nuclear NonProliferation Act of 1978 (NNPA). The act forbids the export of fuel or technology to countries which have not adopted international safeguards on all their nuclear facilities.

President Carter has since overruled the NRC on the grounds that denying India the fuel would seriously prejudice political and economic relationships with India.

The dispute has brought to a head not only strategic differences between Congress and the State Department but also tensions between the United States and India rampant ever since India exploded a nuclear device in 1974.

Mrs Gandhi's return to power last year, and her subsequent firm refusal to eschew the possibility of India developing its own nuclear weapons, put an end to hopes that agreement could be reached. Now the Administration is trying to persuade Congress that political tensions in South Asia, and the consequent advantage of remaining on good terms with India, should override more narrowly focused policies.

The Administration and its critics find themselves on opposite sides of a narrow dividing line. The NRC, for example, taking a strict interpretation of the NNPA, refused to grant an export licence partly on the grounds that the shipment of the fuel would take place more than two years after the NNPA had been signed, the grace period for compliance. But the Administration points out that the request had been received in 1977; that the delays were the result of US indecision for which India should not be penalized; and that subsequent licence requests will be treated differently.

Then there is the question of whether, if the export licence is granted, it will be used as a precedent by other countries - for example Argentina, Brazil, South Africa and Iraq - to claim exemption from the act. Administration critics are standing firm on this point. The Administration however disagrees.

Another question is whether denying the fuel to India would violate the 1963 agreement, under which the United States guaranteed to provide fuel supplies to Tarapur for 30 years and, if so, whether India would then feel free to ignore other restrictions in the agreement.

"If the US breaks the agreement, then India can do what it wants, including using

a test of nerve in Congress

plutonium from the fuel rods to make nuclear weapons', Dr Betty Lall of the US State Department said at a meeting organized by the Arms Control Association in Washington last week. Others, however, argue that India has long been aware that the obligation of the United States to supply fuel is contingent on India's compliance with US licensing requirements, however these may change.

Strict non-proliferationists favour the big stick. "Congress should draw a clear line and say 'no' to further nuclear commerce with India until the Indian government accepts international safeguards on all its nuclear activities", said a statement issued last week by several public interest groups, including the Natural Resources Defense Council and the Union of Concerned Scientists. The Administration still prefers to use softer methods, arguing that in the long run nonproliferation objectives have a better chance of success through dialogue rather than confrontation.

In Congress, which can overturn the President's decision if both houses agree by a simple majority before 12 September, the issue is in the balance. In the House of Representatives, feelings against the export licence are running high; a majority of members of the Foreign Affairs Committee, for example, have signed a statement calling the decision to grant the licence "a dangerous mistake".

In the Senate, there is also some strong opposition, headed by Senator John Glenn, chairman of the Government Affairs Committee's Energy and Nuclear Proliferation Subcommittee.

In an election year, however, political dynamics could prove crucial. A certain amount of the opposition seems to have been stimulated by a desire to embarrass the Administration. The House committee's statement opposing the licences, for example, was supported by two-thirds of the committee's Democrats, but three-quarters of its Republicans.

The Administration is at present trying to convince a sufficient number of Senate Democrats of the value of treating the licence as a special case, with a promise of further negotiation towards a definite outcome one way or the other. Given that both houses have to concur in any disapproval, the Senate's refusal to do so would be sufficient to allow the export to proceed.

David Dickson

\title{
Plagiarism strikes again
}

The spate of publications with which $\mathrm{Dr}$ E.A. Alsabti has scattered the scientific literature in the past few years now seems destined to be followed by a similar spate of retractions. The accompanying letter (see page 437) from Dr Akiro Shishido, Managing Editor of the Japanese Journal of Medical Science and Biology (JJMSB), says that a notice will appear in the August issue of the journal explaining that the editorial board now considers that Alsabti's contribution to that journal describes research originally carried out by Dr Daniel Wierda and Dr T L Pazdernick, first published in the European Journal of Cancer.

It is not yet known how many of the 23 papers listed in Index Medicus under Dr Alsabti's name are likely also to fall under a cloud. It is, however, known that Alsabti's paper "Lymphocyte transformation in patients with breast cancer", published in the Japanese Journal of Experimental Medicine $(49,101 ; 1979)$ is virtually identical with "The effects of surgery on lymphocyte transformation in patients with breast cancer", published by Dr Sylvia M. Watkins in Clinical and Experimental Immunology $(14,69 ; 1973)$.

As in other papers published under his name, Dr Alsabti acknowledges his gratitude to His Royal Highness Crown Prince Hassan for "financial support and encouragement". To Dr Watkins's original list of references is added in the pirated version the reference "Alsabti, E.A., Lymphocyte transformation in bladder carcinoma, J. Clin. Hematol. Oncol. (1978), in press",

Meanwhile, an apparently unrelated case of plagiarism involving another Jordanian scientist, has come to light. Dr K.O. Kutschke, of the Canadian National Research Council, who is Editor of the Canadian Journal of Chemistry, says that in February 1978 his journal received for publication a manuscript called "Influence of electric charges on the corrosion of metals" a paper previously published by a group of Swedish authors - J.A. Hedvall, Nils-Gosta Vannerberg and P.O. Blomqvist - in Acta chemica scandinavica $(22,363$; 1968).

In that case, Dr Kutschke explained this week, the plagiarized manuscript was not accepted for publication because the list of references included one to the Swedish group whose work had otherwise been pirated. Only curiosity, Dr Kutschke explained, prompted him to look up the original publication, whereupon he recognized the identity of the two papers.

On that occasion, it appears, the Jordanian author (whose name is being withheld) gave an address at a university in the eastern United States, but had given the University of Amman as the location of his research. On complaint from Dr Kutschke, the visiting appointment of the scientist was terminated. 